\title{
Climbing up from the abyss of problem gambling: a story of an international student in New Zealand
}

John Wong

Correspondence: john.wong@pgfnz. org.nz

Asian Family Services at the Problem Gambling Foundation of New Zealand, Auckland, New Zealand

\section{Background}

I was born in China. I came to Auckland, New Zealand to study English when I was 22 years old. Obtaining a tertiary degree in business and marketing was my ultimate goal. During the initial few months, I enjoyed the New Zealand life style very much. I loved the fresh air, the delicious Eastern and Asian food, the kiwi culture, and the beautiful waterfront and beaches. I made new friends who came from everywhere around the world. I was greatly amazed with this new life experience!

\section{Case description and discussion}

Not long after such a honey moon period, I started missing my family and friends in China. The study was very hard, and life was getting tough and boring. Failing to find more interesting activities to engage with, I stayed at home spending much time on computer games which were not really attractive to me. One night a friend, who also came from China to study in New Zealand, took me to a casino. There are no casinos in China, therefore, it was the first time for me to bet on casino table games. I have forgotten if we had lost or had won but I still remember clearly it was an exciting experience. We spent a whole night at the casino. It was much better than staying home to play fighting games on the computer.

Soon after my first visit to the casino, I began going there frequently either with my friends or just by myself. I liked visiting the casino very much. I was curious about how people might win money. I believed that casino was the place where I could get everything I desired including making new friends, killing boredom, passing time, and enjoying the excitement of gambling. I even thought that I could win money as I might improve my gambling skills by gambling more. I started to explore different types of games day and night.

At first I visited the casino only once or twice a week but soon within a two month period, my visit became almost a daily activity. My bets also increased rapidly from one or two dollars to at least five to ten dollars. When I was lucky, I won several hundred dollars. However, I did lose several hundreds in one visit. I experienced a string of ill luck losing my pocket money, my rental fees and even what my parents transferred to me for my study. I had no money to buy food and to pay rent. I was so desperate that I ended up borrowing money from my friends and fellow classmates. I knew that my parents could

(c) 2013 Wong; licensee Springer. This is an Open Access article distributed under the terms of the Creative Commons Attribution License (http://creativecommons.org/licenses/by/2.0), which permits unrestricted use, distribution, and reproduction in any medium, provided the original work is properly cited. 
not afford to send me money. I withdrew from the school to get a refund of the tuition fee so that I could continue gambling to recoup losses. But I lost again and again. I felt extremely guilty after gambling but on the next day I returned to the casino to chase after losses. I avoided meeting friends, classmates and anyone from whom I had borrowed money.

I lied to my parents that I had finished my study. I told them I was going to get a job soon. I did not want to let them down or make them worry about me. I tried to stop going to the casino many times but failed. I felt so depressed and hopeless that I wished I had a car accident and was killed to end all the pain. Fortunately, my girl friend discovered my gambling problem. She encouraged me to seek help from Asian Family Services which provides free of charge and confidential counseling services to problem gamblers in Chinese. I called the Asian Service hotline. My call was a great decision leading to many positive changes.

With mixed feelings and struggles, I went into the counseling room. Out of my expectation, the counselor did not help me solving the financial problems, instead she listened patiently. This was the first time that I experienced unconditional regards. I was not judged as a bad person. I started to share my feelings, reviewed my life and explored hidden issues that I lacked courage to address before. I gained insights into the relationship between my emotions and gambling behavior. I learnt how to manage emotions, rebuilt confidence to deal with gambling related problems. I learned communication skills and improved the relationship with my family and my girlfriend, I learned how to cope with stress, solve problems, and manage debts and money. My life returned to the right track.

\section{Conclusion}

Eventually, I stopped gambling, and got a part-time job to return the money I owed to my friends. I no longer needed to hide myself from them. I continued with my study, and got a university degree. Luckily, I got a job offer. Now, I am married and have a full-time job. I am enjoying my new life without gambling. I have to thank my family and my wife who forgave me, and had never given me up. I would not have achieved anything without their support. I would like to pass an important message here: it is never too later to get ride of problem gambling by seeking professional help. There is hope for making changes.

(This true story was written by John Wong who is the Director of Asian Family Services at the Problem Gambling Foundation of New Zealand, Auckland. The gambler sought help from the service centre.)

Competing interests

The author declares that they have no competing interests.

Received: 2 February 2013 Accepted: 2 February 2013

Published: 1 March 2013

doi:10.1186/2195-3007-3-5

Cite this article as: Wong: Climbing up from the abyss of problem gambling: a story of an international student in New Zealand. Asian Journal of Gambling Issues and Public Health 2013 3:5. 